\title{
The Biopolitics of Media Currency: Transforming the Ghana Film Unit into TV3
}

\author{
Peter J. Bloom ()
}

\begin{abstract}
This article is an examination and extension of concepts that Achille Mbembe presented in his 2016 African Studies Association Abiola Lecture. In particular, "cognitive assemblages" are elaborated upon to consider how a shifting understanding of media has become part of a neoliberal digital media platform promoted by the Ghanaian state in association with Malaysia. Mbembe's invocation of the "injunction to decolonize" is also discussed through information capture and data mining to consider the extent to which the promise of a digital future is a form of neocolonialism or an opportunity for an expanded digital commons.
\end{abstract}

Résumé: Cet article est un examen et un prolongement des concepts présentés par Achille Mbembe durant la conférence Abiola de l'Association d'études africaines 2016. En particulier, les « assemblages cognitifs » sont développés pour examiner comment une compréhension changeante des médias est devenue une partie intégrante de la plate-forme médiatique numérique néolibérale promue par l'État ghanéen en association avec la Malaisie. L'appel de Mbembe à « l'injonction à la décolonisation » est également discuté par l'acquisition d'information et l'exploration de données afin de déterminer dans quelle mesure la promesse d'un avenir

African Studies Review, Volume 64, Number 1 (March 2021), pp. 57-70

Peter J. Bloom is Associate Professor and Chair of the Department of Film and Media Studies at the University of California at Santa Barbara. He has published widely on Anglophone and Francophone colonial media, including French Colonial Documentary (2003). His ongoing work has been focused on British colonial film and radio in Ghana and Malaysia. E-mail: pbloom@filmandmedia.ucsb.edu

(C) The Author(s), 2021. Published by Cambridge University Press on behalf of African Studies Association. This is an Open Access article, distributed under the terms of the Creative Commons Attribution-NonCommercial-ShareAlike licence (http:// creativecommons.org/licenses/by-nc-sa/4.0/), which permits non-commercial re-use, distribution, and reproduction in any medium, provided the same Creative Commons licence is included and the original work is properly cited. The written permission of Cambridge University Press must be obtained for commercial re-use. doi: $10.1017 /$ asr.2020.79 
numérique est un type de néocolonialisme ou une possibilité pour un bien commun numérique élargi.

Resumo: Este artigo analisa e aprofunda os conceitos que Achille Mbembe apresentou em 2016, na Lição que proferiu em Abiola para a African Studies Association. Mais especificamente, desenvolve-se o conceito de "montagens cognitivas", para a compreender de que como os media foram alterados no sentido de os tornar parte de uma plataforma digital de media com características neoliberais, promovida pelo Estado do Gana, em parceria com a Malásia. O “apelo à descolonização" lançado por Mbembe é ainda debatido à luz da recolha de informações e do processamento de dados, de modo a avaliar até que ponto a promessa de um futuro digital corresponde a uma forma de neocolonialismo e é uma oportunidade para alargar a partilha de dados digitais.

Key Words: biopolitics; cognitive assemblages; decolonization; digital media; Ghana; Malaysia; privatization; sovereignty

(Received 22 June 2020 - Revised 17 July 2020 - Accepted 28 July 2020)

Achille Mbembe's 2016 Abiola Lecture "Future Knowledge[s]" has served as a stimulus for reconsidering my previous research regarding the nature and context for media as currency in Ghana and Malaysia. Media currency is not only a financial instrument but also a conduit and infrastructure for communication. Just as film and radio were integral to defining communication technologies during the terminal colonial period and in the immediate postcolonial era, digital media has since emerged as the primary representational technology, a mode of transmission and arbiter of value. The legacy of the Ghana Film Unit and its transformation into the first privatized Ghanaian television station with the assistance of Malaysian engineers and managers in the late 1990s demonstrates how a private, individually-centered space of reception has transformed political sovereignty from a national project to a globalized system of personalized values. What began as the Gold Coast Film Unit in 1948 within the context of the British Colonial Film Units became the Ghana Film Unit in 1957. It was then transformed into TV3 and GAMA Films in 1996. The effect of this restructuring not only underscores the migration of film to television, but also presents a realignment in relation to emerging forms of digital communication technologies including the mobile phone-a device that Mbembe has identified as a psychic and social instrument that reorients human activity.

Knowledge of this historical transition is critically important because it points to a biopolitics of infrastructure that comes to redefine the relationship between political and financial sovereignty. It is from this standpoint that media as currency emerges as an information-based concept of value on the order of securitized bitcoin algorithms whose role and value are guaranteed 
as an assertion of political sovereignty. Media thus becomes instrumental to a rearticulation of sovereignty, subject to what Mbembe refers to as new "cognitive assemblages." This implies an alternate nomenclature for media as information technologies within a global context that is aligned with the dynamics of markets. The consideration of cognitive assemblages and references to "plasticity" as both integral to conceptions of new digital media and a precolonial African cultural inheritance in Mbembe's lecture serves as a vanishing point for the discussion that follows.

In his influential essay "Necropolitics" (2003), Mbembe does not merely emphasize the thematic of death and "necropower" during the period of late colonial occupation, but he also emphasizes the underlying role of sovereignty, which exercises control over the instrumentalization of bodies (or, as Michel Foucault writes, the power and capacity of the sovereign to dictate who may live and who must die [Foucault 2003:240]). Sovereignty remains relevant to an understanding of media and its effect upon the marketization of the public sphere. Just as Mbembe's conceptualization of necropolitics supplements Foucault's notion of biopolitics, media currency relies on the very same scaffolding of biopolitics. At the same time, however, it represents a pivot toward an accelerated series of ontological turns, such as the dematerialization of the sovereign as a sign from a gold coin to a one-of-a-kind algorithmic calculation to which a quickened pace of transactional value exchange becomes enabled. It is in this sense that Mbembe's notion of cognitive assemblages may also be said to incorporate the construct of media currency.

An ongoing debate regarding the terms of "cognitive capitalism" may advance this transformation in extending Mbembe's formulation of assemblages. As Michael Peters has described, cognitive capitalism may be understood as a third stage of capitalism, in which the accumulation process is centered on immaterial assets, utilizing immaterial or digital labor processes along with the production of symbolic goods and experiences (Peters \& Bulut 2011). Antonio Negri (2018) has also specified a reliance on a new regime of information and communication technologies that has become indebted to the creation of value; this is based on the social capture of value rather than the extractive labor associated with industrial capitalism. While this terminology might serve as a gloss on the contemporary implications for media currency, its biopolitics are grounded in the shifting terms of sovereignty. Whereas Mbembe's approach to necropolitics addresses colonial legacies of compartmentalization, the shifting relationship between sovereignty and media leads us back to biopolitics because it points to an emerging context for extracting rents on the basis of data reception, storage, and transmission with profound effects on governmentality, or what has been rearticulated as infrastructure. It also redirects questions about shifting contexts for the rule of capital, particularly on the African continent. 


\section{Algorithms of Race, Gender, Sexuality, and Species}

Before turning to an earlier archival-based history of media materiality in Ghana and its transformation into a dematerialized digital media apparatus, I would like to invoke Mbembe's discussion of the "rewiring" of cognitive processes allied with the advent of instantaneous media technologies of magnification and simultaneity because of its underlying relationship to changing conceptions of media. His reference to increasingly invasive techniques of mapping human and animate subjectivity may, in fact, be understood as a refashioned colonial project through increasingly significant representations of incubatory zones in the biological, medical, and behavioral sciences. The redistricting of "bare life" through techno-scientific digital technologies is an especially fraught development. Its embrace may, in fact, imply that an earlier critique of colonialism as an extension of scientific and bureaucratic positivism may be cast aside. Nonetheless, the critique of a colonizing positivism has been a central feature in asserting the injunction to decolonize. It is within these terms that Mbembe's interest in grappling with the shape of decolonized knowledge may lead us to reconsider its complex relationship to more visible "compensatory acts," synonymous with assertions by W.E.B. Du Bois. ${ }^{1}$

The insistence on the neutrality of data as quantity to the deficit of a series of contextualized relationships circumvents a critique of human developmentalism. As a result, a new postcolonial paradigm of scientific cognition must imply a context for reform while incorporating diverse "algorithms" of race, gender, sexuality, and species. With new tools of data collection sharpened and methodologies hybridized, a new sphere of knowledge acquisition continues. While there are significant insights in determining diagnostic and predictive values within the terms of controlled scientific experiments, their relationship to colonial categories remains ambiguous and of a different quality. For this reason, pointing to new discursive "turns" within the terms of cognitive assemblages as scientific-like may in fact justify a form of rearmament and a recalibration of invasive strategies in search of an unknown territory both within the body, under the earth, and in the planetary beyond. As Mbembe suggests, the empirical validity of these new approaches has become further refined and calibrated thanks to an array of prospecting instruments, ballistic technologies, and methodologies. However, these technologies often emphasize a population-centric approach, as opposed to a human-centered one, as part of an adaptive regime of quantification. It is in this sense that the critical insight of Ian Hacking's insistence on a "dynamic nominalism" (2002) remains relevant, in that it suggests that any descriptive or theoretical strategy must take into account how society changes and constantly adapts to new ways of living.

Instead of invoking the unity of planetary time syncopated to the measurement of minutes on the smart phone or fear propagated within the terms of the Anthropocene as a new dimension of geological time, the challenge of post-colonial imperialism may be the recalibration of critical dialectical 
methods. Within these terms, we may then consider the unreal state of digital media in the mediation of consciousness. The notion of hybridization, learning communities, or new thought collectives seem to perpetuate human factors and engineering that claims newness as an enlightened and expedient solution-based approach to organizing community, notwithstanding its reliance on a corporatist social model. Instead, as Mbembe suggests, we must address how claims regarding new technologies herald a new human and social conjuncture. We can revive our own address to deeper histories, particularly an African spiritual approach to the plasticity of knowledge, because it sheds light on genealogical foundations that inform the uses and adaptations of contemporary objects of study, such as the mobile phone. As a techno-scientific machine, the mobile phone may stand in as a machine of wonder and enchantment.

\section{The Computational and African Plasticity}

As Mbembe asserts, the poor African urban dweller strives to acquire a mobile phone first and foremost, and then television or cable TV. These markers of modernity serve as a gateway to an elsewhere beyond their own community, as part of an expanded network of communication. At the same time that there is a will to be connected globally, there is an ongoing interest by mobile phone companies and Internet service providers to extend the electromagnetic grid to not only enable access for "users" but also to determine how these mobile devices are being used. ${ }^{2}$ The process of respatialization underway has supplanted the paradigm of one-way radio transmission. Radio was used initially as an administrative instrument of political communication that created a context for education, entertainment, and news. Radio and television have since become dominated by private stations with a dizzying array of channels in a global network.

The Internet and mobile telephony more generally provide yet another cultural extension for inhabitants on the continent. I am not sure that the widespread use of the mobile phone on the African continent can be understood as contributing to an "Afropolitan aesthetic sensibility" per se, as Mbembe suggests. Acts of communication are certainly enabled by it and may act as cultural extensions of logistical and gestural performances. Instead, the uses of these devices function in the same way as they do elsewhere. That is, the mobile phone functions as an invasive instrument of technological transformation that simultaneously depersonalizes and connects us. If the means of production for decision-making, manufacture, and assembly, as well as ownership and computer coding, exist elsewhere, the manner in which we use them locally remains circumscribed within a dynamic of the global circulation of value. Further, these continually updated devices and applications are, in fact, borrowed within a temporal landscape of access. ${ }^{3}$ The desire for new technologies such as the smart phone may, in fact, reinforce an ongoing process of disenfranchisement, in 
spite of pervasive claims about enablement, individual rights, or an aesthetics of distinct stylization.

While it might seem that we own the electronic devices that we use to communicate, the relationship to intellectual property and the terms of ownership for our own pictures, recordings, texts, and other snapshots of our own daily lives exist in and appear under a cloud. These devices and accompanying apps may be used for messaging or voice conversations, and the companies that provide these services consistently seek ways to retain our "data," be it through cloud storage or among other methods that imply a collective loss of personal ownership. While this is organized as a convenience for users and held in the name of confidentiality, ongoing instances of data breaches and surveillance-based infiltration loom large. Mobile electronic technologies, such as smart phones, have been understood as archives in and of themselves, or greniers, as Mbembe describes them, for storage and retrieval that have quickly become a new language of tool-making within a communication process. But, once again, under what conditions do they remain within our grasp?

To invoke "plasticity," we must define the agency of the "user." The question of how plasticity functions and for whom has been an ongoing subject of public debate. I am led back to the adaptation of African aesthetics associated with the European avant-garde in the era of Dada, and the manner in which pre-colonial ritual masks, textiles, sculpture, and everyday objects were appropriated into Western works of art. These works, such as the Kongo minkisi (power figures), were initially crafted to establish a locus of community power (LaGamma et al. 2015). Their less than well-known integration into the hybrid quality of a circulating modernity lends itself to an order of authorship and aesthetics of display within institutional and private settings. While the granular quality of colonial networks, art dealers, gallerists, artists, and museums has become better understood from a historical perspective, the advent of African ingenuity, or the plasticity of African pre-colonial cultures, may not provide a key to understanding the structure of digital media. Instead, African aesthetic signs continue to be appropriated as a resource to be mined. In other words, the digital media economy functions on the basis of capture, accumulation, and reappropriation within the terms of an expanded financial and institutional infrastructure. Imperial in its ambition, this economy of data collection thrives on setting parameters for accumulating information about animate subjects in order to gain profit. That is, the expansion of an epistemological paradigm that claims to be globally inclusive may in fact be a means of disenfranchising the local by means of stratification and gentrification, and through the promotion of private interests through public and international policy. Further, these longstanding techniques may enable the providers of new technologies to extract and repackage local and social meanings in a more extensive rentseeking structure of consumption. 


\section{Liquidity of Media: The Ghana Film Unit and Malaysian TV3}

The desire to participate in the world of contemporary digital media and global user networks as a thematic on the African continent is a formative and increasingly prevalent market dynamic with a number of significant implications. While it remains unclear whether it may claim purchase on a new infrastructure of the unconscious, its quickly accreted totems have already contributed to a more widely shared sense of deterritorialization and relocation. We can then consider capital in relation to media as a conjuncture, and invoke Zygmunt Bauman's notion of liquid modernity in its metaphoric appeal to digital infrastructure and plasticity as a form of flexibility that had been likened to postmodernism, and yet integrated into the everyday rhythms of life (Bauman 2000). By means of example, I would like to further discuss a case study that I have followed concerning a Global South network of exchange that involved the leasing of the Ghana Film Unit by a Malaysian media company that transformed it into a private television station known as TV3. While this leasing agreement was brokered by longstanding prime ministers in power with the benefit of loyal political party patronage, the transformation of the Ghana Film Unit's production infrastructure into a television production studio implies a transnational dynamic that reinforces a privatized context for projecting images of national identity and power.

The 1996 majority transfer of the Ghanaian national film production unit to a Malaysian media concern for USD1.4 million over a fifteen-year period demonstrates how film production as a convertible national asset is implicated in the transnational politics of accumulation, and its eventual dematerialization as data streaming. The state "divestment" from the Ghana Film Industry Corporation (GFIC) was reported in the Ghanaian press and described in significant detail by political economists and social anthropologists. ${ }^{4}$ The divestment from GFIC culminated in a leasing agreement between the government of Ghana and the Malaysian media enterprise Sistem Televisyen Malaysia Berhad (STMB). ${ }^{5}$ This arrangement was part of a larger portfolio of Ghanaian state assets leased to Malaysian companies within the bumiputera corporate polyarchy that took over 70 percent of the equity, with the Ghanaian state retaining a 30 percent stake and often less. The GFIC divestment in particular was a significant event, precisely because it refers to an earlier image of Ghana's national identity on the one hand, endowed with the narrative qualities of cinematographic projection, and Malaysia's geopolitical ambitions on the other. It is also a means of engaging with how past knowledges, in the form of archives, are buried in favor of new media formats and a reconfiguration of political alliances.

The GFIC was a production unit, film archive, and theatrical exhibitor initially derived from the British colonial Gold Coast Film Unit (GCFU), first established in 1948, that was set up on parallel footing to the Malayan Film Unit founded in 1946. The GCFU was renamed the Ghana Film Unit upon independence in 1957, until it was reorganized and incorporated as the GFIC in 1961; it remained as such until being dissolved in 1996, then spun off into 
GAMA [Ghana-Malaysian] Film Corporation (GFC) in association with TV3, which became the first independent television station in Ghana (Jørgensen 2001:122-24). ${ }^{6}$ The production facility was constructed on a geographically adjacent site to the Accra campus and headquarters of the Ghana Broadcasting Corporation (GBC), with whom there was an informal sharing of resources and personnel.

\section{Political Partnership and Strategies of Accumulation in the Global South}

The shifting context for national film production and exhibition in Ghana is symptomatic of a technological and industrial shift. It has contributed to the transformation of film into media, and then communication data that implies a new geography of circulation and privatized meanings. Contemporary film and media production, like the increasingly arcane notion of "telecommunication" technologies have become consolidated as digital technologies of data transfer. The advent of TV3 and GFC was part of a transnational regime of investment, labor management, and new techniques of specialization. Malaysia had anticipated this shift toward the creation of a digital infrastructure; it figured as a central feature in the Malaysian $2020 \mathrm{New}$ Economic Plan (NEP) that was widely emulated not only in Ghana, but also in South Africa in the immediate aftermath of Apartheid (Padayachee \& Valodia 2002). In addition, the new investment regime for digital restructuring contributed to the advent of the Malaysian Multimedia Super Corridor (MSC), which was based on the entrepreneurial model of Silicon Valley. It was anchored by the newly built city of Cyberjaya that was part of a major urban rebuilding project in Putrajaya, the Administrative capital now twinned with the adjacent political capital city of Kuala Lumpur. Josh Lepawsky has described the development of the MSC as an anti-politics machine to the extent that it was designed not only to depoliticize but also to suspend political and social rights of the working citizenry as part of a neoliberal Anglo-American investment regime (2009:475).

Transformation in the means of production is an ongoing process, but more crucially, the dynamics of respatialization in film and media among other related industries has had significant effects on the globalized political arrangements of power and patronage. While the technological transformation of an increasingly defunct film unit might have been potentially necessary in retrospect, the disregard for its archive of film and television production points to a restructuring of the past within the present. While most of the remaining film prints on site were in a deteriorated state years prior to the restructuring effort, largely due to a lack of infrastructure, the privatizing strategies remain compatible with historical patterns of statedriven ownership reinforced by transnational political party alliances. ${ }^{7}$ In fact, Max Horkheimer's "Notes on Rackets" [Die Rackets und der Geist] (1985) remains relevant insofar as it describes how particular types of interest groups seek to acquire a share of "circulating surplus value" through "strategic positioning" (Stirk 1992:141). This insight reveals how exogenous political 
party allegiances, along with internal dynamics, played a significant role in the global recalibration of value.

It also leads us to examine the significance of "divestment" from the perspective of political party alliances between Ghana and Malaysia, given their shared British colonial legacy and relationships of patronage within the multinational banking and corporate sectors. It was the congruence of these political party organizations that functioned as an exogenous postcolonial context of exchange and value within the neoliberal context for privatization. The longer historical context for this partnership is directly related to the preindependence era, particularly during the period of trusteeship leading to independence in Ghana between 1951 and 1957. British resistance to independence took shape at various sites of the British Empire in the form of military operations within the context of counterinsurgency campaigns, as in the case of Kenya and Malaya (i.e., Peninsular Malaysia and Singapore). It has been persuasively argued that this immediate postwar period may be understood as the Fourth British Colonial Empire from 1945 to 1957, reinforced by the ascendancy of the Conservative party between 1951 and 1957. However, the underlying economic context for independence was subsumed by an international financial system that retained the power of value within an export commodity market structure. ${ }^{8}$

The partnership between Ghana and Malaysia in the 1990s drew on their histories as significant nodes of the British Empire aligned through lucrative cocoa exports in the case of the former and rubber and tin in the case of the latter. This meant that with the rising costs of British goods during the postwar era, other imports had always flowed in because a lack of government control created intermittent alternatives to the London commodities exchange, including the emerging dollar economy (Morgan 1980:7-8). It can be claimed that Ghana and Malaysia's shared year of independence in 1957 facilitated a unity of nationalist sentiment and a future transnational bond. The subsequent partnership between the two countries provided a strategic opportunity for the increased involvement of international financial institutions. The terminal phase of the Cold War during the 1980s was yet another significant transformative period that became allied with the widespread global phenomenon of privatizing state assets, particularly within the Anglo-American sphere of emergent neoliberalism, which is both a claim about communication technologies and geography.

\section{Divestment as a Semiotics of New Media Infrastructures}

Divestment belies the larger context for privatization that became an overriding agenda of the Thatcher government (1979-1990), leading to a significant phase in the dismantling of the British welfare state. Initially, Thatcherism captured a sizable dimension of public support in Britain through politically popular projects that included the privatization of public housing. In fact, thousands of families living in public housing became homeowners through government sales of such units (Jomo 2008:199). 
Stuart Hall (1993) has described the conservative authoritarian populism that Thatcherism roused through housing, among other initiatives, as being closely allied with race and Englishness. These themes served as a unifying ultimatum that drew on a belated internalization of imperial categorical imperatives. Neoliberal policy prescriptions under Thatcherism were leveled in the name of efficiency that came to be affiliated with Reaganomics, its supply-side variant, and an expanding cadre of solicitous policy experts. The reshuffling of state assets in the name of a conservative politics with its own economic school of thought closely associated with the Chicago School was then adapted as a dominant perspective by international financial institutions. In evoking themes of globalization as integral to the privatization of the GFIC, it is important to specify how these transformations served as scaffolding for extending the strategic exercise of authority and political control in Ghana and Malaysia.

The terminology of divestment, which is another means of referring to privatization, refers not just to a vocabulary of subtraction but also to a quality of indeterminacy and speculative opportunity. Divestment became a means by which to reclaim the GFIC as a vehicle for international investment to supplement government prerogative and realign social expectations. From this perspective, investment was partially conceived in relation to financial considerations while at the same time mandating new institutional forms. The alliance of international political parties served as an underlying institutional context for asserting more subtle forms of investment in the reframing of sovereignty under the banner of a neoliberal financial regime. It also becomes a means by which to straddle various types of global interests and constituencies, repositioning the state apparatus as part of an extended privatized sphere.

The shifting financial context for investment as well as platforms for exhibition and display have always been integral to film and media production, but the nature of this transformation leads us back to questions of geopolitical aesthetics, along with the attendant fragmentation and reshaping of a shared subjectivity. Divestment as restructuring does not mean the disappearance of the cinematic theatrical effects in the conversion to digital formats and increasingly privatized settings. Instead, the divestment exercise was part of a historical cycle that repositioned symbolic objects of the immediate past in the service of remaking the present. It might thus be understood as a shifting context from one set of historical declinations allied with the institution of cinema to another defined by global media transfer. As a format of theatrical display, the cinema has always been understood as an industrial art form of representation. However, a modernist mid- to latetwentieth century aesthetic context transformed into an archival reservoir of historical precedent and citation. Furthermore, the era of television from the mid-1960s onward, when many of the GFIC films were produced, served as a gateway toward increasingly mobile production units and instantaneous "live" transmission feeds that shifted the context for viewing. 


\section{The Biopolitics of Media Currency}

The story of the GFIC divestment in relation to the Malaysian media context is part of a more complex set of issues that I have only briefly excerpted in the preceding discussion. Nonetheless, it remains relevant as a counterpoint to Mbembe's Abiola Lecture because it queries how a population-centered market dynamic has become bound up with new media formats and electronic devices such as the smart phone. An emerging sphere has been established beyond the temporality of cinema and theatrical projection. The space of cinema-going publics was transformed into privatized sites for media consumption. The status of what might be termed a transnational new media dispositif cannot be easily aligned with stable identity formations, but relies on an increasingly concentrated context for infrastructure development that facilitates transmission and reception (Casetti 2015). The manner in which the circulation of media increasingly addresses a new kind of subjectivity may be understood within an emerging biopolitical basis for media reception as integral to a conceptual mapping of the body. This is different from asserting that it infiltrates or structures human consciousness. We might use microscopic cameras to perform delicate surgical operations, drones to survey distant landscapes, or acoustical devices as a form of surveillance. However, the utility of these media instruments remains within a scientific modality of measurement and performance of particular actions. The indispensable utility of media from this perspective may be contrasted with its function within the terms of spectacle, such as news or entertainment, among other more specific cinematic and cultural genres.

Transformation in the uses of media relies on the terms of infrastructure, and the question of how it is managed and structured around particular kinds of vital interests involves longstanding political alliances. From this perspective, the underlying arrangements of political power that mobilize these projects seek their own gain, perhaps in the form of "discharge" as Béatrice Hibou (2004) has acutely described, but it most certainly relies upon converting public assets into private ones. This implies that the study of how control of this infrastructure is exercised in defining media as a type of commodity is at once external while also in the process of becoming internalized. We might say that the consolidation of media is based on the dynamic relationship between ownership and sovereignty. It is from this perspective that interrogations of digital media on the African continent must continue to be scrutinized such that the injunction to decolonize remains an active response to the concentration of powerful interests. It remains a critical project of unmasking, in the spirit of Mbembe's intervention, relying on a set of new terms that goes beyond an instrumentalist view of knowledge as merely a matter of the paradigmatic relationship with power. Instead, it is the search for a "horizontal strategy of openness to dialogue among different epistemic traditions," as Mbembe asserts, that goes beyond celebrating self-proclaimed counter-hegemonic financial consolidation that all too often disables a context for struggle through misdirection and privatization of the commons. 


\section{References}

Ansah, Eric Schubert. 2006. Close Encounters between Africa and Asia: Ghana's Look East Policy and the Making of Malaysia's Overseas Investors. Ph.D. diss., University of Amsterdam.

Bauman, Zygmunt. 2000. Liquid modernity. Cambridge: Polity Press, Blackwell.

Bloom, Peter J., and Kate Skinner. 2009-10. "Modernity and Danger: The Boy Kumasenu and the Work of the Gold Coast Film Unit." Ghana Studies 12-13: 121-53.

Casetti, Francesco. 2015. The Lumière Galaxy: Seven Key Words for the Cinema to Come. New York: Columbia University Press.

Crary, Jonathan. 2014. 24/7: Late Capitalism and the Ends of Sleep. New York: Verso.

Darwin, John. 2006. "Was there a Fourth British Empire?" In The British Empire in the 1950s: Retreat or Revival? edited by Martin Lynn, 16-31. New York: Palgrave Macmillan.

Foucault, Michel. 2003. "Society Must Be Defended”: Lectures at the Collège de France, 19751976, translated by David Macey. New York: Picador.

Garritano, Carmela. 2013. African Video Movies and Global Desires: A Ghanaian History. Athens, Ohio: Ohio University Press.

Gomez, Terrence, and K.S. Jomo. 1999. Malaysia's Political Economy: Politics, Patronage and Profits. Cambridge: Cambridge University Press.

Hall, Stuart. 1993. "The Local and the Global: Globalization and Ethnicity." In Culture, Globalization and the World-System: Contemporary Conditions for the Representation of Identity, edited by Anthony D. King. Binghamton, New York: Macmillan.

Hacking, Ian. 2002. "Making up people (1986).” In Historical Ontology, 99-120. Cambridge, Mass.: Harvard University Press.

Hibou, Béatrice, ed. 2004. Privatizing the State, translated by Jonathan Derrick. New York: Columbia University Press.

Jomo, K.S. 2008. “A Critical Review of the Evolving Privatization Debate.” In Privatization: Successes and Failures, edited by Gérard Roland, 199-212. New York: Columbia University Press.

Jørgensen, Anne Mette. 2001. "Sankofa and Modern Authenticity in Ghanaian Film and Television." In Same and Other: Negotiating African Identity in Cultural Production, edited by Maria Eriksson Baaz and Mai Palmberg, 119-41. Stockholm: Nordiska Afrikainstitutet.

LaGamma, Alisa, et. al. 2015. Kongo: Power and Majesty. New York: The Metropolitan Museum of Art.

Lepawsky, Josh. 2009. "Clustering as Anti-politics Machine? Situating the Politics of Regional Economic Development and Malaysia's Multimedia Super Corridor." Regional Studies 43 (3): 463-78.

Mbembe, Achille. 2003. "Necropolitics." Public Culture 15 (1): 11-40.

Meyer, Birgit. 2001. "Money, Power and Morality: Popular Ghanaian Cinema in the Fourth Republic." Ghana Studies 4: 65-84.

—. 2003a. "Ghanaian Popular Cinema and the Magic in and of Film." In Magic and Modernity: Interfaces of Revelation and Concealment, 200-22, edited by Birgit Meyer and Peter Pels. Stanford: Stanford University Press.

— 2003b. "Visions of Blood, Sex and Money: Fantasy Spaces in Popular Ghanaian Cinema." Visual Anthropology 16 (1): 15-41.

- 2015. Sensational Movies: Video, Vision, and Christianity in Ghana. Berkeley: University of California Press. 
Morgan, David J. 1980. The Official History of Colonial Development, vol. 2. Developing British Colonial Resources, 1945-1951. London: Macmillan Press.

Mullen, Bill V., and Cathryn Watson, eds. 2005. W.E.B. DuBois on Asia: Crossing the World Color Line. Jackson, Miss.: University of Mississippi Press.

Murphy, Philip. 1995. Party Politics and Decolonization: The Conservative Party and British Colonial Policy in Tropical Africa, 1951-1964. Oxford: Clarendon Press.

Negri, Antonio, ed. 2018. From the Factory to the Metropolis, translated by Ed Emery. Cambridge: Polity Press.

Oelbaum, Jay. 2002. "Populist Reform Coalitions in Sub-Saharan Africa: Ghana's Triple Alliance.” In Canadian Journal of African Studies 36 (2): 281-328.

Padayachee, Vishnu, and Imraan Valodia. 2002. "Developing South-South Links? Malaysian Investments in Post-Apartheid South Africa." In Ugly Malaysians? South-South Investments Abused, edited by K.S. Jomo, 29-46. Durban, South Africa: Institute for Black Research.

Peters, Michael, and Ergin Bulut, eds. 2011. Cognitive Capitalism, Education, and Digital Labor. New York: Peter Lang.

Rice, Tom. 2019. Films for the Colonies: Cinema and the Preservation of the British Empire. Oakland, Calif.: University of California Press.

Shipley, Jesse W. 2004. “'The Best Tradition Goes On': Audience Consumption and the Transformation of Popular Theater in Neoliberal Ghana." In Producing African Futures: Ritual and Reproduction in a Neoliberal Age, edited by Brad Weiss, 106-40. Leiden: Brill.

Stirk, Peter M.R. 1992. Max Horkheimer: A New Interpretation. Exeter: Harvester Wheatsheaf.

\section{Notes}

1. This is drawn from W.E.B. Du Bois's writings on the "color line" thesis, first mentioned in 1900 and continuously elaborated upon until the 1960s (Mullen \& Watson 2005).

2. Many of these companies on the African continent are South African-owned enterprises with myriad streams of international investment.

3. Jonathan Crary's invocation of time shrinkage resulting from new technologies of media is of great interest, as he develops the concept in parts of 24/7: Late Capitalism and the Ends of Sleep (2014).

4. From the perspective of political economy in Ghana see Ansah (2006), Oelbaum (2002), and from a Malaysian perspective see Gomez and Jomo (1999). The most detailed scholarship about the relationship between Ghanaian cinema and the divestment has been described by Birgit Meyer (2001, 2003a, 2003b, 2015); see also Carmela Garritano's work on Ghanaian "video-movies” (2013), and for a related discussion of "concert parties," see Shipley (2004).

5. STMB was initially set up as part of a Malaysian government initiative in 1983 to launch TV3, the first private television station in Malaysia.

6. More specifically, the Gold Coast Film Unit was initially bundled with West Coast Pictures Ltd. upon independence in 1957 in order to create a national distribution outlet for national newsreels and documentary films. The first phase transformed the Gold Coast Film Unit into the Ghana Film Unit from 1957 to 1962. After Sean Graham left Ghana in 1958, Charlie Knott, the sound technician, took over as interim head of the unit until Nkrumah appointed Kofi Awoonor as the 
first Ghanaian managing director of the film unit from 1960 to 1963 . He was then followed by Sam Aryeetey in 1963, followed by Reynold Ofoe Fenuku (dates and precise succession remain unknown), A. Harruna Attah from 1982 to 1985, and Chris Hesse from 1985 to 1995. From this point forward, Hesse continued to play an oversight role, but Victor E. K. Anti served as director from 1995 to 1997, and then Berefi Apenteng from 1997 to 2000. For a more extensive discussion of the Gold Coast Film Unit, see Bloom and Skinner (2009-10), and Rice (2019).

7. It should be noted that all of the former personnel at the GFIC were horrified by the destruction of archival records and films held at the GFIC. Chris Hesse explained that when he got wind of this incident, he personally intervened to see that many of the films would be transferred to the Information Services Department. Nonetheless, it has been claimed that many important documents and films were burned on the GFIC campus in 1996 or 1997. Films and documents remain in storage at the Information Services Department but are not being capably maintained, and the film inventory is plagued with vinegar syndrome.

8. For further discussion, sources, and nomenclature related to the so-called "Fourth" colonial Empire, see Darwin (2006:16-31). It should also be noted that the changing resonance of Empire in British public discourse had shifted dramatically by the late $1950 \mathrm{~s}$, such that Conservative candidates were careful not to evoke the imperial greatness of yester-year. From 1951 to 1957, the Conservative Party was in power, with Winston Churchill (1951-55) and Anthony Eden (1955-57) serving as prime ministers and associated with significant late colonial counter-insurgency campaigns. For further discussion see Murphy (1995:9). 